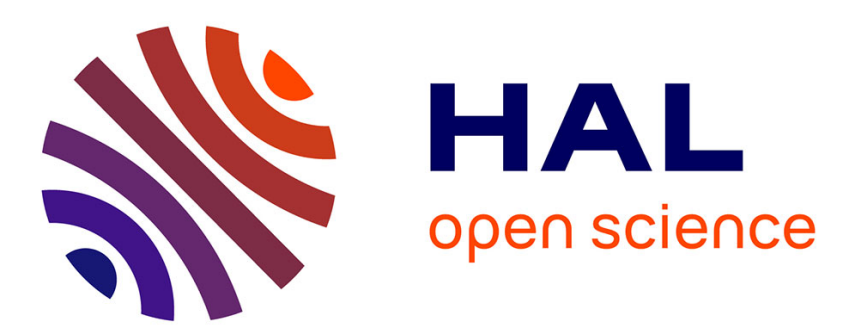

\title{
Transport properties of conducting polythiophene-polystyrene composites
}

F. Samir, M. Morsli, A. Bonnet, A. Conan, S. Lefrant

\section{To cite this version:}

F. Samir, M. Morsli, A. Bonnet, A. Conan, S. Lefrant. Transport properties of conducting polythiophene-polystyrene composites. Journal de Physique IV Proceedings, 1993, 03 (C7), pp.C71565-C7-1568. 10.1051/jp4:19937244 . jpa-00251882

\section{HAL Id: jpa-00251882 https://hal.science/jpa-00251882}

Submitted on 1 Jan 1993

HAL is a multi-disciplinary open access archive for the deposit and dissemination of scientific research documents, whether they are published or not. The documents may come from teaching and research institutions in France or abroad, or from public or private research centers.
L'archive ouverte pluridisciplinaire HAL, est destinée au dépôt et à la diffusion de documents scientifiques de niveau recherche, publiés ou non, émanant des établissements d'enseignement et de recherche français ou étrangers, des laboratoires publics ou privés. 


\title{
Transport properties of conducting polythiophene-polystyrene composites
}

\author{
F. SAMIR, M. MORSLI, A. BONNET, A. CONAN and S. LEFRANT*
}

Université de Nantes, Laboratoire de Physique des Matériaux pour l'Electronique, E.A. 1153, 2 rue de la Houssinière, 44072 Nantes cedex 03, France

*Institut des Matériaux de Nantes, Laboratoire de Physique Cristalline, 2 rue de la Houssinière, 44072 Nantes cedex 03. France

\begin{abstract}
:
Experimental results on electrical conductivity and thermoelectric power for ( $\mathrm{FeCl}_{3}$ - doped polythiophene) - polystyrene composites have been performed in the temperature range $77-300 \mathrm{~K}$ and with polythiophene content in the vicinity and exceeding the percolation threshold. The thermoelectric power observed experimentally exhibits a surprisingly nearly linear behaviour versus $\mathrm{T}$ related to the slightly thermally activated electrical conductivity variations. All these results are analyzed in terms of hopping mechanisms. A model involving both the intrinsic resistance of the polythiophene domains and the resistance of the junctions between these domains is considered. The reduction of $\mathrm{Fe}^{\mathrm{III}}$ in $\mathrm{Fe}^{\mathrm{II}}$ during the polymerization reaction is discussed on the basis of XPS analysis results.
\end{abstract}

\section{Introduction :}

Polythiophene (PTh) can be easily prepared by both electrical polymerization [1] and chemical polymerization [2,3]. Highly conducting Pth with conductivites in the range $10-100 \mathrm{~S} / \mathrm{cm}$ have been obtained [1]. Several attempts have been undertaken in order to improve the mechanical properties and processability. Recently, conducting polythiophene composites have been prepared using a one-step oxidative reaction of $2-2$ - bithiophene with ferric chloride [4]. They are based on highly porous crosslinked polystyrene as host polymer. Polystyrene is first imbibed with a solution of $2-2^{\prime}$ bithiophene in acetonitrile. The saturated host polymer is then partially dried and imbibed again with a solution of $\mathrm{FeCl}_{3}$ for polymerization to occur. 


\section{Experimental :}

The composites which we have prepared according to this procedure are environmentally stable and reach conductivities as high as $25 / \mathrm{cm}$ at room temperature. The polythiophene content which depends upon the $\mathrm{FeCl}_{3}$ /bithiophene molar ratio ( $\mathrm{y}$ ) is in the vicinity of the percolation threshold for two composites and above it for five other composites.

At room temperature, d.c. electrical conductivity ranges from $4 \times 10^{-6} \mathrm{~S} / \mathrm{cm}$ for the less "doped" composite ( $y=0.17)$ to $2 \mathrm{~S} / \mathrm{cm}$ for the highly "doped" one $(y=2.9)$.

Figure 1 presents the effect of the $\mathrm{FeCl} 3 /$ bithiophene molar ratio on the conductivity of the composites. It puts in evidence that the conductivity is a result of the formation of an electrical network of polythiophene inside the composite. The low conductivities must be attributed to the small amounts of PTh that are formed and to the low connectivities among the deposited PTh domains : there are no macroscopically connected paths. Above the percolation threshold which is found at about $y=0.31$, a large number of connected paths are generated among the PTh domains which lead to a relatively high conductivity.

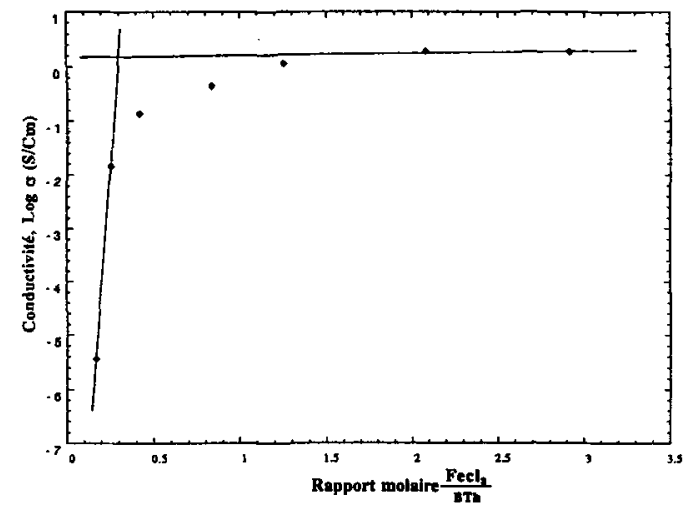

Fig 1-Conductivity of polythiophene composites vs $\mathrm{FeCl}_{3}$ /bithiophene molar ratio

Electrical conductivity and thermoelectric power measurements have been performed for five composites $(y=0.25,0.42,0.83,1.25,2.08)$ in the temperature range $77-300 \mathrm{~K}$, using a method described previously [5,6]. Figure 2 presents the logarithm of the electrical conductivity variations versus $10^{3} / \mathrm{T}$. Variations are weakly thermally activated : the activation energy is about $40 \mathrm{meV}$ for the less "'doped" conducting composite and decreases down to $20 \mathrm{meV}$ for the highly "doped" one. 


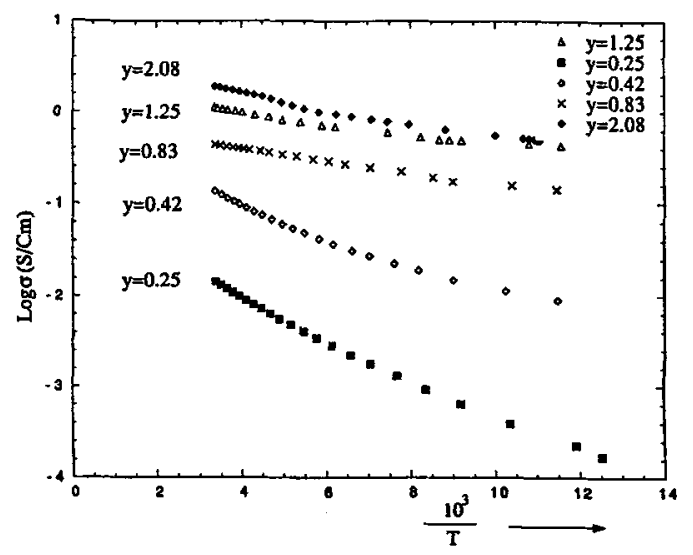

Fig 2 - Experimental variations of $\log _{10} \sigma$ vs $10^{3} / \mathrm{T}$ obtained on five polythiophene composites

The thermoelectric power variations versus $T$ are shown on figure 3 . The T.E.P. which is small and positive for all the composites decreases with the $\mathrm{FeCl}_{3} /$ bithiophene molar ratio from $28 \mu \mathrm{VK}^{-1}(\mathrm{y}=0.25)$ to $10 \mu \mathrm{VK}^{-1}$ $(y=2.08)$ at room temperature.

For each composite, the T.E.P. exhibits a surprisingly nearly linear behaviour versus $\mathrm{T}$. The slope is found to be about $0.09 \mu \mathrm{V} \mathrm{K}^{-2}$ for $\mathrm{y}=0.25$ and 0.035 $\mu \mathrm{V} \mathrm{K} \mathrm{K}^{-2}$ for $\mathrm{y}=2.08$.

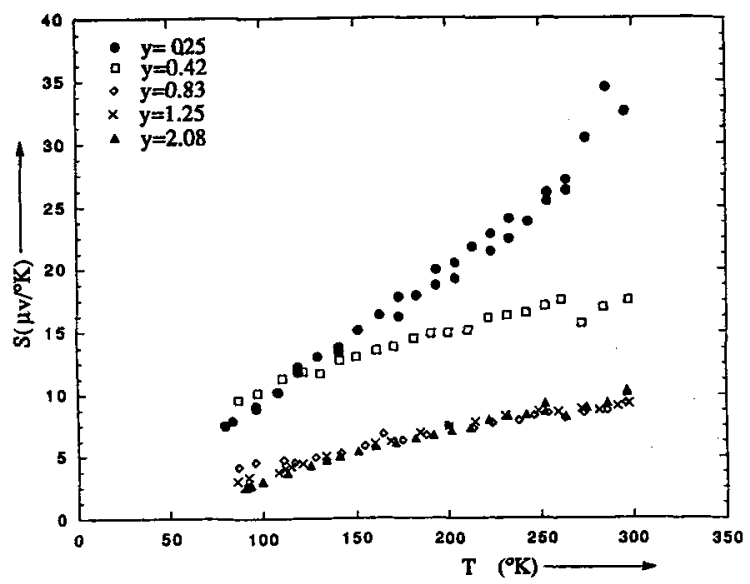

Fig 3 - Experimental variations of the T.E.P. vs $\mathrm{T}$ obtained on five polythiophene composites 


\section{Discussion :}

The T.E.P. linear behaviour provides evidence against explanations of the conductivity temperature dependence in terms of models in which the number of charge carriers varies with temperature. So all the electrical conductivity results have to be analyzed in terms of hopping mechanisms in which mobility is thermally activated :

- above the percolation threshold, conduction mechanisms are mainly governed by hopping between the polythiophene chains in the PTh conducting domains (intrinsic resistance),

- below the percolation threshold, two main contributions have likely to be taken into account : as in the latter case, hopping between the PTh chains and moreover hopping between conducting domains through the host matrix.

In order to explain the linear T-dependence of the T.E.P., it can be assumed that thermoelectric power in such composites is dominated by conduction mechanisms along the PTh chains over which most of the temperature gradient occurs. So, the standard MOTT formula giving metallic diffusion thermoelectric power linear in temperature can be used :

$$
\mathrm{S}=\left(\pi^{2} \mathrm{kB}^{2} \mathrm{~T} / \mathrm{Be}\right)(\mathrm{d} \ln \sigma(\mathrm{E}) / \mathrm{dE}) \mathrm{EF}
$$

For the composites in the vicinity of the percolation threshold, the conductivity temperature dependence is likely governed by direct elastic tunnelling through thin polystyrene barriers. In this case, the thermoelectric power should also be linear in temperature [7]. However, one might expect the charge carriers to carry more heat and give rise to a larger thermoelectric power. The fact that no strong effect is observed suggests also that the barriers contribute little to thermoelectric power.

First results of XPS studies on polythiophene-polystyrene composites show that the $\mathrm{Fe} 2 \mathrm{p} 3 / 2$ binding energy after etching is located at about $710.55 \mathrm{eV}$. So, it confirms that $\mathrm{Fe}^{3+}$ is reduced to $\mathrm{Fe}^{2+}$ during the bithiophene polymerization.

\section{References :}

1 - Proc. Int. Conf. Physics and Chemistry Low-Dimensional Synth. Met., Abano Terme, Italy, Mol. Cryst. Liq. Cryst., 118 (1985)

2 - K. Kobayashi, J. Chen, T.C. Chung, F. Moraes, A.J. Heeger and F. Wudl, Synth. Met., 9, 77 (1984)

3 - M.B. Inoue, E.F. Velasquez and M. Inoue, Synth. Met., 24, 223 (1988)

4 - E. Ruckenstein and Jun Seo Park, Synthetic Metals, 44, 293 (1991)

5 - A. Bonnet, P. Said and A. Conan, Rev. Phys. Appl., 17, 701 (1982)

6 - M. Makhlouki, M. Morsli, A. Bonnet, A. Conan, A. Pron, S. Lefrant, J. Appl, Polymer Science, 44, 44, 443 (1992)

7- A.B. Kaiser, Phys. Rev. B 40, 2806 (1989) 